\title{
Reform and Application of Improving the Specialized Practice Teaching System
}

\author{
WANG Fang \\ School of Mechatronic Engineering \\ Xi'an Technological University \\ Xi'an, China \\ wangfang0608@sina.com
}

\author{
CHEN Hong \\ School of Mechatronic Engineering \\ Xi'an Technological University \\ Xi'an, China \\ rainbaby@163.com
}

\begin{abstract}
Based on shortcomings of the traditional practice teaching system in packaging engineering specialty in our college, the current traditional model of practice teaching has been reformed and practiced from the aspects of laboratory construction, curriculum design, graduation design, productive practice and teaching material construction according to characteristics of the disciplines and change of industry needs. The results are that establishing a new practice teaching system. Its main characteristics is to improve the students engineering practice ability and enhance the employability and competitiveness of students as a main line of professional training objectives and ability training in real engineering environment so as to meet the need of training applied talents.
\end{abstract}

Keywords-professional construction; formatting; engineering practice ability; practice teaching system; Application type talent

\section{INTRODUCTION}

Since reforming and opening, the development of China's packaging industry has made great achievements with the sustained, rapid, healthy development of national economy and the rapid improvement of people's material and cultural life level. But generally speaking, high level professional and technical talents in Packaging industry is very short, especially composite technology application talents. This not only seriously restricts the improvement and development of the overall quality of the packaging industry, but also seriously undermine competitiveness with the same industry in the world. As a cradle of training qualified personnel, the universities and Colleges that have packaging engineering specialty have the obligations to transport high-quality much needed talents in packaging industry for our country ${ }^{[1,2]}$.

Our school started packing engineering specialty from 2001, discipline and specialty construction has formed its advantages and characteristics after several years of hard work. With the development of higher education reform and the continuous development of market requirements, according to specialized actual conditions, we have reformed present traditional practice teaching mode through many enterprise investigations and information feedback of graduates, and established a new teaching system so as to face real engineering environment, increase students' ability of engineering practice, enhance the employability and competitiveness of students and meet the need of training applied talents.

\section{Professional Basis and Cultivation OBjective}

Packaging engineering specialty is an emerging, crossing and very comprehensive discipline, which involves mechanics, material science, art studies, marketing, sociology, management science, psychology, humanities, and so on ${ }^{[3,4]}$. Based on mechanical engineering science and theory of packaging technology, the specialty includes practical and advanced technology in disciplines. It is a omnibus, stereo and typical comprehensive discipline which contains packing machinery, packing material, packaging design, packaging printing, packaging management and so on. As three major support of packaging engineering, mechanics, material science and art studies have already become quite mature discipline in our college and organic combination of the three is a solid theoretical foundation of packaging engineering.

Mechanics is regarded as the most basic theoretical platform in packaging engineering specialty of our college. Talent cultivation objective in our specialty is cultivating composite type modern packaging engineering talents with good thought politics quality, solid theory foundation, strong ability of application computer, strong ability of engineering practice ${ }^{[5,6]}$. The talents need have a certain economic ideas, innovative consciousness, development ability cooperation spirit and overall quality. The curriculum system settings is not only important approach realizing talent training goal, but also the focus, difficulties and breakthrough point of the teaching reform. The construction of curriculum system is not only the basic task of the discipline construction, but also a basic guarantee for training trans-century composite packaging talents ${ }^{[7,8]}$. So reasonable course system is the key factor to realize effectively talent cultivation objective.

\section{Lack of Traditional Practice Teaching System}

With the rapid development of our country packaging industry, higher education of packaging engineering is also thriving. At present, the higher education of packaging engineering has effectively formed the composite training mode with deep foundation and broad extension. Educational focus of the undergraduate still relies mainly on training students ability to adapt to the market demand. But packaging talents enterprises need not only be composite but also practical.

Traditional practice teaching system of packaging engineering specialty in our college mainly includes laboratory construction, curriculum design, graduation 
design, productive practice and teaching material construction. At present it is mainly reflected in the following aspects that we have done research and practice base.

\section{A. Laboratory construction}

Because of short start time and lack of fund, currently specialized practice teaching is mainly to test the performance of packaging material such as paper and plastic. The experiments are all in accordance with the relevant national or industry standards. Most of the experiments are operating experiment, open designing experiment and comprehensive experiment are less, which experiment content is less and its type is single.

\section{B. Curriculum Design}

Curriculum design has started in packaging technology, packaging machinery design, transport package, packaging decoration design and packaging structure design. According to the characteristics of different courses, design topics were identified by teachers themselves. But because the teachers lack of practice, topic number is less, simulated topic is more, the topic associated with enterprise production practice and scientific research project is less. Design technique, design cycle and evaluation standard are not clear.

\section{Graduation Design}

Graduation design is main practice teaching link of final learning and comprehensive training before graduation. It is an important process to deepen knowledge, broaden the teaching contents, comprehensive summary of student learning, research and practice, comprehensive examination of student comprehensive quality and the ability of engineering practice and an important stage of implementation of undergraduate training objectives. After several years of practice and reform, theory research' graduation design topic is more and the application type topic associated with the engineering practice is more, most of the topics lack of creativity. There are some limitations that improve students' ability of analyzing synthetically and solving practical problems by graduation design.

\section{Productive Practice}

Original production practice adopted the mode that school contacts practice enterprise, the teacher lead the students to visit convergently after students completing most of the professional class. This mode has the disadvantage of short time, incomplete practice content, single practice mode. At present the production practice base construction is basically in the blank, as is not conducive to improving the students' ability of engineering practice.

\section{E. Teaching Material Construction}

Most of the textbooks used in professional theory teaching are general higher education packaging textbooks in 1996. The content of some textbooks is too old, not closely linked with the practical engineering problem and focuses on complex theoretical derivation, some contents focuses on complex theoretical derivation, which affects learning effect to some extent.

\section{REFORM MEASURES OF THE SYSTEM}

Through engaging in the professional theory courses and practice teaching for many years, following reform measures have been made about traditional practice teaching system

\section{A. Laboratory Construction}

According to the number of project funds supported by school, purchase necessary laboratory equipment, develop the platform of design and comprehensive experimental in packaging engineering specialty, increase experimental type and improve the experimental guidance book building about new experimental contents. In the condition of lack of funds, digital simulation technique is applied in the experimental teaching via the virtual instrument technology and proper development tools, virtual laboratory for packaging engineering specialty is established and in order to meet the experimental requirements of students as much as possible.

\section{B. The Curriculum and the Graduation Design}

Strengthen contact with various types of packaging enterprises, get design methods of products and evaluation standard in different types of enterprises, improve the training of their practical ability of professional teachers, actively seek opportunities to practice for young teachers in enterprises, try to get a brother school training opportunities so as to improve the ability of teacher's personal practical engineering, encourage teachers to ask for transverse or longitudinal research project and take part in various types of science and technology competition associated with profession. Through ccumulation and exercise of industryacademy-research cooperation, enhance engineering awareness and ability of practice of the professional teacher to update and guide the curriculum and the graduation design. Gradually upgrade topics of curriculum design, graduation design according to actual situation of industry development, each student has a topic combined closely with engineering practice and scientific research, design results is judged by actual production standards so as to increase the proportion and practicalness of the curriculum and the graduation design gradually.

\section{Productive Practice}

By reforming current single productive practice pattern, boldly attempt to two kinds of mode such as centralized practice and decentralized practice and combines graduation design topic with enterprise. Choose the representative packaging business, establish and stabilize production practice teaching base. Especially decentralized practice mode is that let the students find the professional practice of enterprise, graduation design topics may be determined by the enterprise as far as possible, students be in practice at work purposefully so as to combine textbook knowledge with engineering practice. On one hand, deepen the understanding of knowledge to improve the ability of analysis problem solving, On the other hand it can promote employment. 


\section{Teaching Material Construction}

Teaching material is the knowledge carrier reflecting teaching contents and teaching demands, the basic tool for teaching and the important guarantee to improve teaching quality. We conduct continuously curriculum reform, optimization of curriculum resources according to the revised teaching plan requirements and the actual situation of each course. Also we do teaching material construction step-by-step on the basis of engineering practice in order to meet the needs of teaching and learning.

Summary teaching achievements for many years, absorb scientific theory and advanced scientific and technological achievements from similar materials edited by domestic and foreign colleges and universities, scientific research institutes.

By understanding domestic and international packaging technology and development trend and new technology, new technology, new materials and new equipment of packaging industry in recent years, let these contents added to lectures or textbooks. Update teaching material contents and delete old secondary contents so as to keep up it with the pace of development of the industry.

\section{Practice Result of the Reform about the SYSTEM}

Aiming at the problems of practical teaching system of packaging engineering specialty in our college, some measures have been adopted, and results are as follows:

\section{A. Laboratory Construction}

Due to lack of funds and other reasons, he professional laboratory cannot purchase some expensive laboratory equipment to meet the need of designing and comprehensive experiment. Thus virtual instrument technology has been used in order to build a virtual packaging experiment platform and solve the existing problems in the laboratory construction. At present, some utility softwares have been developed by using Visual $\mathrm{C}++$ such as CAD system of cushioning package, transport packaging CAD system and buffer material database, and so on. By these designing and comprehensive experiment platform, a number of software copyright patents have been asked for and authorized. These independent research and development virtual experiment platform can not only build packaging laboratory and improve the utilization rate of the experimental instrument at the lowest cost, but also design and adjust packaging experiment project according to needs to stimulate students' initiative and creativeness and reduce the lab maintenance cost. So virtual packaging experiment is an important means of extending experimental teaching platform and Innovativing experiment project, it is important development direction of packaging laboratory.

\section{B. The Curriculum and the Graduation Design}

After the reform and practice of a few years, the practicability of the curriculum and the graduation design topics has improved dramatically. The proportion of practical design problems gradually increase. The design topics mainly come from the transverse, longitudinal research project and student contest. Teachers' levels have also been further improved, both teachers and students growth level in the design process. For example, some design contents directly come from design and development of a military enterprises such as automatic ammunition fuze plastic box sealing machine, automatic ammunition fuze metal cans packaging sealing machine and empty bottles inspecting machine in the beer packaging production line, double-head aseptic milk packaging machine, milk gable-box packaging machine and so on. Especially the two sealing machine for ammunition fuze, their production capacity and the level of automation is in the domestic leading level. At present, the plastic box sealing machine has applied for and granted three patents for utility models.

\section{Productive Practice}

Production practice is an important practical link in higher education and an indispensable part of strengthening the professional knowledge learningm, strengthening the students' consciousness of engineering and training students' practical ability. After several years of productive practice, we have investigated and analyzed various types of packaging and printing enterprises in Xi'an and surrounding areas. After analysis and comparison, we have chosen fifteen representative packaging and printing enterprise as productive practice sentinel enterprises, these enterprises have the characteristics of advanced technology, high management level, large-scale and good benefit. Especially we have established four practice bases such as Jianlibao (Xi'an) beverage Co., Ltd., Xi'an Bingxin Paper Co., Ltd., Northwest carton packing Co., Ltd. and Xi'an Bosen Biological Pharmaceutical Co., Ltd so as to eliminating the professional practice base blank situation. Also, boldly attempt two kinds of mode of production practice including to centralized practice and decentralized practice. Through a variety of forms such visit, learning, explanation, the report, enable them to have the direct understanding for The social market value and broad development prospect in order to inspire students' professional knowledge and interest and passion of learning.

\section{Teaching Material Construction}

Based on summarizing the teaching results and using for the experience of professional teaching material reform of brother schools, our professional course teachers reform the teaching materials actively according to the specialty cultivation plan and current situation of of industry development. For example, we have written Packaging Machinery Design together with Xi'an University of Technology and independently writen Package Printing and Packaging Engineering Experimental Guide Book. These teaching materials can reflect the latest achievements in applied technology discipline and enhance teaching material practicability.

\section{CONCLUSION}

Through continuous improvement in laboratory construction, curriculum design, graduation designj, productive practice and teaching material construction, practice teaching system has been improved in order to 
accordance with the professional characteristics of packaging engineering and meet industry talent demands. As not only increases the students opportunity to combine theory with practice, but also improve students' engineering practice ability so as to enhance the employability. That enriches the theory courses teaching contents, improves classroom teaching and guiding students' level, strengthen teachers' ability of scientific research and engineering application ability, as makes a meaningful exploration for professional development of packaging engineering. Although we have made some progress, it is a long-term and arduous task improving practice teaching system of packaging engineering specialty. So we must summarize the experience in continuous exploration in order to get more reasonable reform way and operability, meet the social demand for talents and professional development needs.

\section{ACKNOWLEDGMENT}

This research work was supported by teaching reform item funds of the Xi'an Technological University and granted No.12JGZ03.

\section{REFERENCES}

[1] ZHAO Yan and ZHOU Fajiu, "Study on Packaging Talents Training Mode and Subject System Construction,” Journal of Hubei University of Economics. Wuhan, vol. 4, pp. 187-188, May 2007.

[2] YU Zhibin, "Reform on Practical Curriculum System of Packaging Engineering Specialty,” Journal of Zhuzhou Institute of Technology. Zhuzhou, vol. 2, pp. 15-16, Feb. 2006.

[3] WU Ruomei and XIANG Hong, "Research and Reform on Course System of Packaging Engineering Specialty toward the 21 Century," China Packaging Industry. Zhuzhou, vol. 4, pp. 72-73, Apr. 2002.

[4] HUANG Yingwei and YANG Bin, "Discussion on Orientationsearching and Curriculum System of Packaging Engineering Specialty under the New Situation," Journal of Zhuzhou Institute of Technology. Zhuzhou, vol. 5, pp. 74-75, May 2006.

[5] WU Ruomei and WU Xiangjun, "Research and discussion on professional education of packaging engineering specialty for new ideas of packaging business,” China Packaging Industry. Beijing, vol. 10, pp. 59-60, Oct. 2008.

[6] ZHOU Jianwei and WANG Zhenlin, "Investigation and Development Strategy on Packaging Higher education in Changjiang Delta,” Packaging Engineering. Chongqing, vol. 10, pp. 123-124, Oct. 2008.

[7] CAO Le and ZHAO Peng, "Construction of Virtual Packaging Laboratory Based on Virtual Instrument,” Packaging Engineering. Chongqing, vol. 6, pp. 242-244, June 2009.

[8] ZHANG Saoming, "Basic Selection Criteria and Practice Management in Extramural Practice," Chinese Vocational and Technical Education. vol. 3, pp. 34-36, Mar. 2006. 